\title{
The industry effects of information and regulation in the cigarette market: 1950-1965
}

\author{
Carl A. Scheraga \\ Fairfield University, cscheraga@fairfield.edu \\ John E. Calfee
}

Follow this and additional works at: https://digitalcommons.fairfield.edu/business-facultypubs Copyright 1996 American Marketing Association Archived with permission from the copyright holder.

\section{Repository Citation}

Scheraga, Carl A. and Calfee, John E., "The industry effects of information and regulation in the cigarette market: 1950-1965" (1996). Business Faculty Publications. 109.

https://digitalcommons.fairfield.edu/business-facultypubs/109

\section{Published Citation}

Scheraga, Carl, and John E. Calfee. "The industry effects of information and regulation in the cigarette market: 1950-1965." Journal of Public Policy \& Marketing (1996): 15(2), 216-226.

This item has been accepted for inclusion in DigitalCommons@Fairfield by an authorized administrator of DigitalCommons@Fairfield. It is brought to you by DigitalCommons@Fairfield with permission from the rightsholder(s) and is protected by copyright and/or related rights. You are free to use this item in any way that is permitted by the copyright and related rights legislation that applies to your use. For other uses, you need to obtain permission from the rights-holder(s) directly, unless additional rights are indicated by a Creative Commons license in the record and/or on the work itself. For more information, please contact digitalcommons@fairfield.edu. 


\title{
The Industry Effects of Information and Regulation In the Cigarette Market: 1950-1965
}

\author{
Carl Scheraga and John E. Calfee
}

\begin{abstract}
The authors investigate the historical effects of information , ind advertising regulation in the cigarette market. Their method is a series of event analyses, which examines patterns of stock returns of major cigarette sellers during six crucial event periods in the years between 1950 and 1965. They find that the "cancer scare" of 1950, the episode of fear advertising in 1953-54, and the 1962 report by the British Royal College of Physicians adversely affected the market valuations of the companies; however, the 1964 Surgeon General's report and subsequent labeling laws had no significant effect on the stock returns. They also find that the cessation of fear advertising. coincident with FTC policy guides prohibiting such claims, and the FTC-engineered ban on tar and nicotine advertising brought recovery in stock returns, but favored large firms over small firms.
\end{abstract}

$\mathbf{T}$ The cigarette market has long been controversial in this country and elsewhere. Proposals to ban (or at least severely curtail) the advertising and promotion of cigarettes have long been supported by major health organizations, the U.S. Surgeon General, and key members of the U.S. Congress (Warner et al. 1986). In August, 1995, the Food and Drug Administration (FDA) proposed strong restrictions on tobacco advertising, such as limiting most print advertising to "tombstone" advertisements containing no images and little information other than warnings. Sweeping restrictions on tobacco advertising have already been adopted in many other nations.

These events have produced lively discussion of the workings of advertising and other aspects of the cigarette market. This debate has brought forth at least two major issues. The first is the probable effect of current and further restrictions on advertising. Some observers have predicted that a complete ban would bring a reduction in smoking, whereas others have argued that similar measures in this and other countries have had little or no effect on smoking while possibly interfering with beneficial market changes (e.g., Laugesen and Meads 1991; Stewart 1992). A second point of contention focuses on unexpected results. Many observers have argued that previous interventions in the cigarette market suffered from the "law of unintended consequences," in the sense of having done more to protect the industry than promote the welfare of consumers. As is outlined subsequently in a review of the literature, studies have often concluded that major interventions did not bring the market changes presumably sought by regulators and legislators. If previous hopes were frustrated by an inadequate understanding of the dynamics of the cigarette market, it would be wise to investigate these dynamics further before launching a new and more vigorous round of interventions.

Carl Scheraga is Assistant Professor of Business Strategy and Technology Management, School of Business, Fairfield University. JoHn E. CALFEE is Resident Scholar at the American Enterprise Institute, Washington, D.C. Michael Mazis served as editor for this article.
The effects of information and regulation on the cigarette industry's welfare form the focus of this article. Our research takes an approach that differs from most previous studies by directly examining how regulation and other events have affected the welfare of the cigarette industry itself. We do this partly because of the obvious desire to address the issue of unintended regulatory effects, but there are additional reasons for taking a nontraditional approach. These are rooted in the specific type of regulation that has prevailed in this particular market.

\section{Regulation of Cigarettes}

Cigarettes occupy a peculiar regulatory status. Tobacco products have been treated as neither food nor drug, with the effect that political intervention has mainly taken the form of informational regulation.' Essentially, regulation has sought to modify the information environment by providing information directly, requiring sellers to provide information, or restricting the competitive use of information in advertising. Within these constraints, buyers and sellers have been left free to adjust to changing consumer preferences and competitive forces.

Market dynamics have been dominated by informational shocks and regulatory responses since the "cancer scare" of the early 1950s. These shocks (some created by government itself) include: (1) the first widely accepted medical reports linking smoking and cancer, which appeared in the early 1950s; (2) two episodes (in 1953-54 and 1957-60) in which health information induced rapid changes in advertising content, only to have these changes reversed by Federal Trade Commission (FTC) intervention; (3) two major government reports on smoking and health, first from the United Kingdom in 1962 and then from the U.S. Surgeon General in 1964; (4) major antismoking campaigns led by

\footnotetext{
'In August, 1995, the FDA proposed a set of rules for cigarettes and other nicotine-containing products. The FDA proposal did not classify tobacco as a food or drug, but classified cigarettes as a special kind of medical device. Nonetheless, the FDA plan involved regulation of marketing and distribution rather than direct regulation of products (see FDA 1995).
} 
the Surgeon General and other federal officials, beginning in the late 1970s; and (5) a steady succession of updates from the Surgeon General and others on new developments in the analysis of health effects from smoking. Even today, as local regulation has sought directly to restrict smoking in public places (a noninformational form of regulation), the centerpiece of regulatory initiatives in the United States and elsewhere is the proposal to ban or severely restrict cigarette advertising and promotion (FDA 1995; Warner et al. 1986).

Regulation through information, rather than through direct control over production and allocation of resources, presents policy analysts with an interesting set of problems. The informational approach offers several theoretical advantages. These include preservation of individual freedom of choice; accommodation to individual differences in preferences and circumstances; the ability of market participants, including sellers, to change markets without the inefficiencies inherent in command-and-control regulation; and (within limits) the opportunity for market outcomes (rather than post hoc studies of what "would have been") to reveal whether the assumptions and predictions that underlie intervention are valid (cf. Beales, Craswell, and Salop 1981; FTC 1979).

On the other hand, the effects of informational regulation are sometimes difficult to specify, predict, or assess. The freedom of buyers and sellers to adjust to changed conditions makes for ambiguous theoretical predictions about observable market changes. For example, behavioral changes depend strongly on how new information compares with old, but policymakers often have a poor understanding of consumer information before the intervention and may fail to anticipate that information mandated by regulation is not actually "new" to consumers. Also, sellers could adjust their products and advertising in ways that leave equilibrium market sales relatively unchanged despite major changes in, say, the tar and nicotine yield of cigarettes or consumer attitudes toward smoking. ${ }^{2}$

\section{Assessing the Effects of Regulation}

These properties of regulation through information complicate the task of assessing regulatory effects. The usual approach has been to analyze actual market changes in advertising, information, and sales. Several statistical studies have measured the effects on cigarette consumption of the cancer scare of the early 1950s and the series of government actions that began with the 1964 Surgeon General's report and continued through the label warnings required in 1966 and the 1971 ban on broadcast advertising. The results are roughly as follows: The cancer scare apparently depressed sales for at least the short term and perhaps for several years (Ippolito, Murphy, and Sant 1979; Schneider, Klein, and Murphy 1981; Porter 1986; Warner 1979). Health information after 1964 apparently had an impact in the sense of reducing smoking to much less than would reasonably have been predicted for the years after 1964, with some of this probably due to the 1964 Surgeon General's

\footnotetext{
${ }^{2}$ Several studies have analyzed market responses to information in terms of the quantity of tobacco in cigarettes or tar and nicotine content. See Ippolito, Murphy, and Sant (1979); McAuliffe (1988); Schneider, Klein, and Murphy (1981); see also the nonstatistical analysis in Calfee's (1985) study.
}

report (see Bishop and Yoo 1985; Ippolito, Murphy, and Sant 1979; Porter 1986; Schneider, Klein, and Murphy 1981; Warner 1979; Warner and Murt 1982; for a review of previous studies, see Franke 1994; McAuliffe 1987). However, the 1966 warnings apparently have had little independent effect (McAuliffe 1988). In addition, the 1971 broadcast advertising ban, which also ended free antismoking messages broadcast under the Federal Communication Commission's (FCC) fairness doctrine, was probably counterproductive because its net effect was to reduce competition in the market but not to reduce smoking (Eckard 1991; Franke 1994; Simonich 1991; Warner 1979).

Additional insights have come from nonstatistical analyses of market outcomes. The 1965 legislation, which required label warnings but prohibited the FTC from requiring wamings in advertisements, was expected by some observers to benefit the industry (Drew 1965). This and subsequent legislation that mandated warnings were found by federal courts to have preempted liability suits for failure to warn (Cipollone $v$. Liggett Group. Philip Morris, and Lorillard 1992). A few analysts, looking at the neglected era before the 1964 Surgeon General's report, have suggested that FTC advertising regulation in the 1950s and early 1960s may have protected cigarette sellers from their own competitive, self-destructive tendency to seek market share by exploiting fear of smoking (Calfee 1985, 1986; McAuliffe 1988; Ringold and Calfee 1989, 1990).

These results suggest taking a different approach to analyzing the effects of regulation on the cigarette industry. A researcher can employ methods that address directly the question of how information and regulation affected the financial state of the industry itself. We here look at stock returns of the major cigarette sellers, using what has become known as event analysis to isolate unexpected or unusual changes in the returns of cigarette sellers. ${ }^{3}$ This method has two advantages: The first is that stock prices are the surest guide to the extent to which events were expected to confer benefits and costs on individual firms or industries. This is important in view of the suggestion from previous research that regulation may have done little to promote the putative goals of improving information and reducing smoking, while protecting the interests of the cigarette industry itself (Calfee 1987). A second advantage is that market valuations may anticipate later events that are important to consumers or policymakers. In some circumstances, for example, a decline in stock returns could presage a decline in sales that will occur after information known mainly to industry analysts later becomes known to smokers; but we must be careful to avoid ascribing more knowledge to market participants than was available at the time. For example, it is far from clear that anyone could forecast the reaction of consumers to the new health information emerging in the 1950s, nor could anyone easily forecast how individual firms would respond to the complex mix of new health information, new advertising themes, and changed consumer perceptions.

\footnotetext{
${ }^{3}$ We look only at the five major U. S. cigarette firms, whose identities remained unchanged during the periods we analyze. Brown \& Williamson. the remaining firm among the top six, was a British company and therefore not traded on the U.S. stock exchange. None of the results stated here apply to Brown \& Williamson.
} 
The only other work we are aware of in this genre is the study by Mitchell and Mulherin (1988). Their event analysis found that actions leading to the 1971 broadcast banwhich the industry had supported-were associated with positive returns to the cigarette industry. ${ }^{4}$ This finding, combined with the results of other statistical studies indicating that the ban was associated with an increase rather than a decrease in smoking, strongly suggests that the net effect of the 1971 broadcast advertising ban was to benefit the cigarette industry.

\section{Background and Hypotheses}

The cigarette market in the years from 1950 to 1965 was dominated by several remarkable events: publicity about the first widely credited academic reports linking smoking with cancer, a brief outburst of controversial advertising that sought to exploit smokers' fears, federal intervention in 1954-55 to halt this advertising, a vigorous "tar derby" in 1957-59 during which some sellers advertised tar and nicotine content, federal intervention in 1960 to halt the tar and nicotine advertising, the appearance in 1962 of a major British government report finding that smoking causes cancer, the arrival in January 1964 of the first major U.S. government report on smoking and health, and finally, in 1965 , legislation requiring warning labels. Previous analysis has looked mainly at cigarette sales in assessing the effects of these and later events. It is clear from a cursory examination that though the cancer reports buffeted the industry during 1950 through 1952, sales at first continued to rise and then abruptly fell during 1953 and 1954. Per capita sales then resumed a strong upward course that was not disturbed until the 1964 Surgeon General's Report, after which sales quickly rebounded in 1965 and then fluctuated around the 1964 level until commencing a steady decline in 1975 (Maxwell 1986).

\section{The Cancer Scare: 1950-54}

In 1950, two medical journals published studies demonstrating a strong statistical link between smoking and lung cancer. ${ }^{5}$ A follow-up study appeared in 1952 (Doll and Hill). In 1953 came the results of a laboratory experiment in which cigarette tar applied to the skin of a mouse caused cancer, followed in 1954 with yet more epidemiological results (i.e., Doll and Hill 1952, 1954; Wynder, Graham, and Croninger 1953). All these reports received extensive publicity and aroused discussion about the possibility that the cancer scare would adversely affect cigarette sales. The magazines, Consumer Reports and especially Readers Digest, with its vast readership, also played an important role. Consumer Reports published articles on smoking and health in June 1952, February 1953, and December 1953, and Readers Digest, which had long campaigned against smoking, published articles in December 1952 (Norr 1952), December 1953 (Lieb 1953), and July 1954 (Miller and

\footnotetext{
${ }^{4}$ The industry had volunteered to implement a broadcast ban on its own, provided the appropriate antitrust exemption could be obtained (see Miles 1982).

${ }^{5}$ Doll and Hill (1950) and Wynder and Graham (1950): the latter includes a useful review of previous studies dating back to 1912. Also see the reviews by the U.S. Public Health Service (1964) and Wynder (1988).
}

Monahan 1954). ${ }^{6}$ In particular, in the July 1954 Readers Digest article, Miller and Monahan summarize the new epidemiological and laboratory evidence in a manner that attracted widespread attention. Yet the evidence on smoking and cancer was far from overwhelming in the eyes of the public health community; the American Cancer Society, for example, did not take a position on this issue until 1957, and even then it advised smokers only that there was a "suspicion" that smoking "increase[s] the likelihood of developing lung cancer" (Consumer Reports 1957; Miller and Monahan 1954). The U.S. government took no position at all until a brief statement by the Surgeon General in 1957 (Burney 1958).

Unfortunately, it is difficult to specify precise "events" that might have a distinct effect on the market. What was emerging was not merely evidence on smoking and health, but also evidence on how the press treats medical results and on smokers' reactions to such information. Nonetheless, we begin our analysis with the most obvious hypothesis, namely, that new adverse health information reduced the market valuation of cigarette firms during the period of the first early and significant reports in 1950.

\section{Fear Advertising: 1953-54}

Another, perhaps unexpected development during these same years was a new departure in product development and cigarette advertising (for a more general treatment of the content of cigarette advertising over time, see Ringold and Calfee 1989, 1990). Before 1953, Brown \& Williamson's Viceroy brand was the only filtered brand from a major manufacturer, and its market share was negligible. Late in 1952, Lorillard, one of the smallest of the six major cigarette firms, introduced a new brand called Kent-with a filter that was remarkably effective in removing nicotine and tar from cigarette smoke. Liggett \& Myers, another of the smaller firms, introduced its filtered L\&M brand in 1953, and filter brands from the other four major firms followed in 1954 (Miles 1982). Especially notable were the new advertising campaigns devised by the smaller four firms (the two largest firms, American Tobacco and R. J. Reynolds, controlled approximately $60 \%$ of the market.) These firms advertised their filter brands (and some nonfilter brands) in ways that blatantly appealed to health fears: "The cigarette [Philip Morris] that takes the FEAR out of smoking" (Business Week 1953a, p. 54); "Here's how you can get the protection you need against nicotine and tars" (Consumer Reports 1953a, p. 66); "[Kent] takes out more nicotine and tars than any other leading cigarette-the difference in protection is priceless" (Wagner 1971, p. 82); Viceroy's “double-barrelled protection" (Business Week 1954, p. 83); and the new L\&M filter was "just what the doctor ordered" (Wagner 1971, p. 83). ${ }^{7}$

\footnotetext{
${ }^{6}$ Useful historical reviews of early publicity about smoking and health are contained in Ford. Ringold, and Rogers's (1990) and Troyer and Markle's (1983) studies.

${ }^{7}$ Most extreme were advertisements for fringe brands such as De-Nicotea (a de-nicotinized cigarette from Dunhill), with the headline, "Is There A Risk In Smoking?" followed by text that starts, "You have been reading articles recently about the ill effects which may result from cigarette smoking" (New York Times 1954). Also see Brecher (1963).
} 
This kind of advertising became known as fear advertising. It was controversial, not least of all because many industry insiders and observers were certain the advertisements increased rather than allayed fears, and helped only the advertised brands (building from small market shares) and the small firms selling them, while hurting larger sellers and, therefore, overall cigarette sales. Business Week, Consumer Reports, and other magazines attributed part of the unprecedented sales decline of 1953 and 1954 to this outbreak of fear-based advertising. ${ }^{8}$

The advent of fear advertising is another important event in the cigarette market. Fear advertising was widely noted in the popular and trade presses during 1953 and 1954. It came to an end as a result of a set of cigarette advertising guides from the FTC. First circulated in late 1954 and formally issued in 1955, the guides made clear that the Commission would prosecute any seller whose advertising contained references "to either the presence or absence of any physical effect of smoking"(FTC 1955). ${ }^{9}$ The trade press celebrated the cessation of health-related advertising as a factor in the rapid upturn in sales in 1955 and through the rest of the decade (Fortune 1953, 1963; Wootten 1956, 1957, 1958).

A second hypothesis, therefore, is that the fear advertising of 1953-54 helped the four smaller firms but hurt the two largest, and the imposition of the FTC Guides in 1955 had the opposite effect.

\section{The 1960 FTC Ban on Tar and Nicotine Advertising}

In 1957 came additional health shocks in the form of more rigorous epidemiological studies relating smoking and lung cancer, a public recognition (without a formal report) by the Surgeon General that the link was probably causal in nature, and recommendations by nongovernment cancer experts that smokers use cigarettes with substantially reduced tar and nicotine yield (Burney 1958; Wynder 1988). This expert advice, amplified by two striking stories in Readers Digest (Miller and Monahan 1957a, b), promptly led to an outburst of tar and nicotine advertising, which similar to the fear advertising five years earlier, was confined to the smaller four firms (Calfee 1985). A tar derby raged for two and a half years, during which time tar and nicotine yield declined substantially in virtually all brands, filtered and

\footnotetext{
${ }^{8}$ See Business Week (1953b, p. 145):

[T]here is no question but that the tobacco companies themselves have helped cause the sales drop ... [the advertising/ scared some smokers out of the cigarette habit by claiming that each brand of cigarette does not contain the 'harmful ingredients' that others do ... pushed filter mouthpiece cigarettes with advertising that has not only turned many smokers from conventional cigarettes, but, in addition, scared some smokers away from cigarettes entirely.

Also see Fortune (1953, 1963)-as well as Business Week (1954, p. 58), in which motivation expert Ernst Dichter is cited and it is argued that fear advertising "may boost an individual brand's share of the market, but what good is that if the whole market dwindles." See Brecher and colleagues' (1963) study, as well as Wootten's $(1956,1957,1958)$ studies, the latter author being an industry advertising expert who invariably cited the apparent end of the "health scare" when describing the rapid growth in sales in the late 1950s. For a fuller discussion, see Calfee $(1985,1986)$ and Ringold and Calfee (1990) and sources cited therein.

${ }^{9}$ The guides (FTC 1955) explicitly exempted appeals to taste or pleasure from legal attack. The exact chronology is laid out in Calfee's (1985) study.
}

nonfiltered, and the market share of filtered brands increased dramatically. In 1959, five firms (all but R. J. Reynolds) introduced new filtered brands, most of which had less measured yield than existing brands. As of December 1959, most of these new brands were still in an introductory phase of a brand life cycle and were heavily dependent on tar and nicotine advertising.

During December 1959 and January 1960, the FTC secretly negotiated an agreement among all six cigarette firms to institute a "voluntary" ban on all tar and nicotine claims in advertising, justifying this action by the fact that no studies had yet shown health benefits from reduced tar and nicotine (FTC 1960; Kintner 1960). The ban was announced on February 5, 1960. Press reports made clear that the smaller firms strongly objected to the ban because it would impede acceptance of the newly introduced generation of low-tar brands. On the other hand, some industry analysts believed that the end of explicit tar and nicotine claims would help the market overall. ${ }^{10}$

The February 1960 tar and nicotine advertising ban forms a fairly precise event. Our hypothesis is that the smaller firms were hurt relative to larger ones. This is apparently consistent with industry expectations at the time the ban was instituted. ${ }^{11}$

\section{The 1962 Report of the Royal College of Physicians} Early in March 1962, the Royal College of Physicians (1962, p. 57), a British organization, released Smoking and Health, a report that concluded that smoking is a cause of lung cancer and bronchitis and "probably contributes to the development of coronary heart disease and various other less common diseases." This report was well-publicized in the United States and was a factor in President Kennedy's decision in June 1962 to ask the Surgeon General to convene a special committee to produce a report on smoking and health (Wagner 1971, Chapter 8). The Royal College report was not the only significant development in smoking and health during 1962 and 1963. Readers Digest published articles in June (1962) and August (1963a, b) describing not only the British report but also antismoking activity of various kinds in the United States and abroad. The U.S. Air Force ended its practice of providing free cigarettes at its hospitals, the American Heart Association began its campaign against smoking, and most cigarette advertisements were pulled from U.S. college newspapers. We hypothesize that these events, particularly the introduction of the Royal College report, had an adverse effect on cigarette stock returns. The Royal College report has hardly been noticed in subsequent studies of the cigarette market, perhaps because there was no immediate change in sales trends and perhaps also

\footnotetext{
${ }^{10}$ The New York Times (1960, p. 8) quoted a cigarette manufacturer spokesman as saying. "Whether people like it or not, it's going to be a lot easier on the cigarette business." The story noted that some observers expected that R. J. Reynolds and American Tobacco would directly benefit from the ban, but the same would not be true for Liggett \& Myers and Brown \& Williamson, which had been counting on success for new low-tar brands, such as Duke and Life (see also Fortune 1963).

${ }^{11}$ The New York Times (1960, p. 8) noted that the industry generally thought that American Tobacco and R. J. Reynolds would gain from the ban, whereas Liggett \& Myers and Brown \& Williamson were especially vulnerable because of their recently introduced low-tar brands.
} 
because much thinking about the cigarette market in this country has been dominated by the successive Surgeon General's reports, each of which looks back fondly on the 1964 report. As with the original cancer studies, it is difficult to specify a period over which the report would have an effect, because no one knew how consumers and the industry would react to this document, but we expect the impact to appear mainly in the short run (i.e., in 1962).

\section{The 1964 Surgeon General's Report and the FTC's Proposed Trade Rule}

In January 1964, the Surgeon General released a report by its select committee on smoking and health. The report, whose conclusions mainly mirrored those of the 1962 Royal College of Physicians report, was carefully guarded from the public before its tumultuous release. The FTC immediately announced its intention to construct a trade rule that would, among other things, require health warnings in advertisements (FTC 1964; Miles 1982). The FTC action was eventually halted by Congress in the 1965 law that brought the Surgeon General's warning to package labels (Wagner 1971).

\section{Methods}

The seminal paper by Fama and colleagues (1969; hereinafter termed FFJR) defined the basic event study methodology used in numerous studies to examine the effect of new information on asset prices. This approach estimates a market model,

$$
R_{i 1}=\alpha_{i}+\beta_{i} R_{m i}+\epsilon_{i t},
$$

where

$$
\begin{aligned}
R_{i t} & =\text { return of company i`s stock during time period } t \text { and } \\
R_{\mathrm{mt}} & =\text { return on the market index. }
\end{aligned}
$$

The model is estimated with data that includes the period of the event of interest. The residuals from Equation 1 are used to measure abnormal returns for the firms in the sample during the event period. These abnormal returns are cross-sectionally averaged across firms during the event period. The null hypothesis that the average abnormal return equals zero can then be tested.

This approach, however, is not suitable for the problem at hand. The FFJR method assumes that the residuals are independent and identically distributed. Binder (1985) describes three problems with this assumption:

1. Abnormal returns are likely to differ across firms.

2. Previous studies suggest that the variance of the residuals will differ across firms.

3. The residuals will not be independent if the event occurs during the same calendar time period for some firms and these firms are in the same or related industries. The dependence is especially severe when these two conditions hold for all the firms in the sample.

In addition, many of the events of interest in this study represent periods of distinct regulatory regimes rather than single points in time. Information is continually assessed and reassessed throughout such time windows. A method is required that addresses Binder's concerns while also measuring the effects of regulatory regimes over a complete event period. Such an approach is described by Binder (1985) and Rose (1985), where

$$
R_{i t}=\alpha_{i}+\beta_{i} R_{m t}+\sum_{a=1}^{A} \delta_{i a} D_{a t}+u_{i t} .
$$

The variable $\delta_{\text {ia }}$ measures the average excess return over the particular regulatory regime period $a$, and the dummy variables $D_{a t}$ equal one during the $a^{\text {th }}$ event period and zero otherwise. This technique yields a single estimate of average abnormal returns for each event period, rather than accumulating abnormal returns for each time unit within event periods. Hence, there are no cumulative abnormal returns, in contrast to FFJR's much-used method. We also note that because this method applies statistical tests to the average excess return for an entire period, it is biased against finding a significant effect from an event whose effects are shortlived relative to the length of the event period.

Data on monthly returns were obtained from the Center for Research in Security Prices (CRSP) at the University of Chicago. The Center for Research in Security Prices provides monthly rather than daily data for years before July 1962 . We also used monthly data through the 1964-65 event period (described subsequently) to maintain consistency with our other results and provide a longer time series within which to analyze earlier events. (It has been argued that for this particular type of study, monthly returns are more desirable than daily returns; see Lubatkin and Shrieves 1986.) The return on the market is measured by the CRSP equally-weighted monthly market index (denoted EMINDEX in our tables). Research using monthly data often involves long event periods; analysis of mergers, for example, has typically used 60-month event windows (Lubatkin and Shrieves 1986). None of our event periods are this long, though one extends through 24 months.

Equation 2 defines a system of returns-generating equations, one for each company. Each equation can be estimated by a single regression encompassing all event periods, nonevent intervening periods, and several months before the first period (which began January 1950) and after the last period (which ended December 1965).

When the explanatory variables are the same for each firm in the sample, the system of equations can be jointly estimated by using the methodology of the seemingly unrelated regression model (Zellner 1962). This enables abnormal returns to differ across firms. This technique assumes that the disturbances within each firm equation are independent and identically distributed. An additional assumption is that across firm-specific equations, the contemporaneous covariances of the disturbances are nonzero, whereas the noncontemporaneous covariances are all identically equal to zero. These assumed characteristics of the disturbances presuppose that the observations for each equation in the sample are from the same time period, which is true in the case at hand.

Rose (1985) and Smith, Bradley, and Jarrell (1986) note that the magnitude of the response of equity capital (across firms) to particular events is influenced by the degree of leverage of individual firms. Hence, Equation 2 is augmented in the following manner: 


$$
\mathrm{R}_{\mathrm{it}}=\alpha_{\mathrm{i}}+\beta_{\mathrm{i}} \mathrm{R}_{\mathrm{mt}}+\sum_{\mathrm{a}=1}^{\mathrm{A}}\left[\frac{1}{\left(1-\mathrm{DEBT}_{\mathrm{i}}\right)}\right] \delta_{\mathrm{ia}} \mathrm{D}_{\mathrm{at}}+\mathrm{u}_{\mathrm{it}},
$$

where $1 /\left(1-D^{-D B T_{i}}\right)$ is the inverse of the share of equity in firm i. Because market values of debt are not readily available, estimates of these shares use book values. Although this approach may be less than ideal, it is common and does begin to incorporate leveraging effects into the final results. Equation 3 is used to test hypotheses about individual firms.

Because the explanatory variables are the same for each firm equation, the estimated coefficients and standard errors are identical to the estimates obtained from ordinary least squares estimation of the individual equations. The advantages to this approach are with regard to hypothesis testing, because such hypothesis tests incorporate heteroscedasticity across equations and the contemporaneous dependence of the disturbances. In particular, in addition to individual significance tests on each of the $\delta_{\mathrm{ia}}$, the joint, intraequation hypothesis is tested, where

$$
\mathrm{H}_{0}:\left(\frac{1}{N}\right) \sum_{i=1}^{N} \delta_{\mathrm{ia}}=0
$$

is the hypothesis that the average abnormal return for event period a equals zero. ${ }^{12}$ This hypothesis is of particular interest for two reasons: First, it allows for an examination of the statistical significance of an event period for the industry as a whole (minus the small British firm, Brown \& Williamson). Second, the expression, $(1 / \mathbb{N}) \Sigma_{i} \delta_{i a}$, corresponds to the average of the event-period average excess return found in the traditional FFJR analysis.

Another hypothesis is tested to examine any differential effects of a particular event period between large firms (American Tobacco, R. J. Reynolds) and small firms (Lorillard, Liggett \& Myers, Philip Morris). Thus,

$$
\mathrm{H}_{0}:\left(\frac{1}{\mathrm{~N}}\right) \sum_{1.2} \delta_{\mathrm{ia}}=\left(\frac{1}{\mathrm{~N}}\right) \sum_{3,4.5} \delta_{\mathrm{ia}}
$$

where

$$
\begin{aligned}
& 1=\text { American Tobacco, } \\
& 2=\text { R. J. Reynolds, } \\
& 3=\text { Lorillard, } \\
& 4=\text { Liggett \& Myers, and } \\
& 5=\text { Philip Morris. }
\end{aligned}
$$

\section{Event Periods}

Following Binder (1985), the system of equations defined by Equation 2 was estimated over a period beginning several months before the first month of the first event period and ending several months after the last month of the last event period. Six event periods were identified, with the $i^{\text {th }}$ period denoted by a dummy variable $D_{i}$. As was discussed by Binder (1985), discretion must be used in defining the event periods. It is critical to identify the most important event periods rather than simply include every related event

\footnotetext{
${ }^{12}$ Discussion of the F-test for this joint hypothesis and that defined by Equation 4 can be found in Theil's (1971) study.
}

period. If this is not done, detection of statistically significant market reactions is not possible. The event periods we discuss subsequently were constructed to capture the major economic and regulatory milestones outlined previously. ${ }^{13}$ Nonetheless, there is an unavoidably arbitrary element in our choices. We emphasize, however, that these event periods were specified before data collection and that we deliberately avoided respecifying event periods in order to find a better or more interesting "fit" between hypotheses and data. The latter activity could yield suggestive results but would not be hypothesis testing. We did conduct a simple post hoc sensitivity test to assure ourselves that our results were not being driven by events peripheral to our main interest. As we describe, each window was constructed to begin two months before the regime of interest and end two months afterward. We then reran the regressions, using event periods that began one month before and ended one month after. Results were qualitatively unchanged.

The first event period, January 1950 to December 1950, begins approximately two months before the publication of the first of the significant cancer articles in the Journal of the American Medical Association and ends approximately two months after the article in the British Medical Journal. This period was chosen to allow for uncertainty in the exact date of publication of particular articles as well as to give the market sufficient time to react to new information.

The second event period spans the period of fear advertising from September 1953 to August 1954. This time period was chosen because it coincided roughly with the height of this type of advertising, as was widely remarked in the press (e.g., Business Week 1953a, p. 54). It also includes the period of the widespread introduction of filter cigarettes, as well as the publication of the highly visible articles in Consumer Reports (1953a, b) and Readers Digest (Miller and Monahan 1954).

The third event period is the period of the FTC cigarette advertising guides. These guidelines were informally circulated in September 1954, but it was not until September 1955 that the guides were officially issued and placed into effect. We chose the period of July through November 1955 to provide sufficient time for the market to react to final issuance of the Guides.

The fourth event period spans December 1959 to December 1961. This again allows for a two month buffer before the February 1960 FTC "voluntary" ban on all tar and nicotine claims in advertising. The period ends two months before the release of the Report of the Royal College of Physicians in March 1962. This choice of event period should thus allow for a careful examination of the differential impact of this new and largely unexpected regulatory regime on large versus small cigarette companies. We note that such a difference in impact was anticipated in the press.

\footnotetext{
${ }^{13}$ We reviewed the Wall Street Journal index while constructing event periods. This failed to reveal other notable events likely to substantially and permanently affect market prices within our event periods. This exercise also was useful in determining an appropriate length for event periods. For example, the index revealed that public discussion of the 1964 Report continued at a high level through the middle of 1965 .
} 
Table 1. Seemingly Unrelated Regression Estimation Results for Equation 3

\begin{tabular}{|c|c|c|c|c|c|}
\hline \multicolumn{3}{|c|}{ A. American Tobacco } & \multicolumn{3}{|c|}{ B. R. J. Reynolds } \\
\hline Variable & Parameter Estimate & t-Statistic & Variable & Parameter Estimate & t-Statistic \\
\hline INTERCEPT & .004393 & 1.060 & INTERCEPT & .011724 & $2.313^{* *}$ \\
\hline EMINDEX & .629320 & $7.515 * * *$ & EMINDEX & .591088 & $5.769 * * *$ \\
\hline D1 & -.016607 & $-2.286^{* *}$ & DI & -.024155 & $-2.334 * *$ \\
\hline D2 & -.019996 & $-2.531 * * *$ & D2 & -.024325 & $-2.178 * *$ \\
\hline D3 & .017456 & 1.409 & D3 & .021109 & 1.224 \\
\hline D4 & .015327 & $2.080 * *$ & D4 & .020037 & $2.094 * *$ \\
\hline D5 & -.039050 & $-3.270^{* * *}$ & D5 & -.056906 & $-3.759 * * *$ \\
\hline D6 & .005100 & .586 & D6 & -.014693 & -1.343 \\
\hline
\end{tabular}

C. Lorillard

\begin{tabular}{|c|c|c|c|c|}
\hline Variable & Parameter Estimate & t-Statistic & Variable & Para \\
\hline $\begin{array}{l}\text { INTERCEPT } \\
\text { EMINDEX } \\
\text { D1 } \\
\text { D2 } \\
\text { D3 } \\
\text { D4 } \\
\text { D5 } \\
\text { D6 }\end{array}$ & $\begin{array}{r}.014981 \\
.610792 \\
-.024153 \\
-.021042 \\
-.012648 \\
.002446 \\
-.028225 \\
-.014309\end{array}$ & $\begin{array}{c}2.479 * * \\
4.999 * * * \\
-1.837 * \\
-1.931 * \\
-.813 \\
.257 \\
-1.958 * * \\
-1.361\end{array}$ & $\begin{array}{l}\text { INTERCEPT } \\
\text { EMINDEX } \\
\text { D1 } \\
\text { D2 } \\
\text { D3 } \\
\text { D4 } \\
\text { D5 } \\
\text { D6 }\end{array}$ & \\
\hline \multicolumn{5}{|c|}{ E. Philip Morris } \\
\hline & Variable & Par & er Estimate & t-Statistic \\
\hline & $\begin{array}{l}\text { INTERCEPT } \\
\text { EMINDEX } \\
\text { D1 } \\
\text { D2 } \\
\text { D3 } \\
\text { D4 } \\
\text { D5 } \\
\text { D6 }\end{array}$ & & $\begin{array}{l}05071 \\
34863 \\
09033 \\
30308 \\
15301 \\
11962 \\
29634 \\
01255\end{array}$ & $\begin{array}{c}1.201 \\
6.265^{* * *} \\
-.990 \\
-2.967^{* * *} \\
.984 \\
1.735^{*} \\
-2.751 * * * \\
-.184\end{array}$ \\
\hline
\end{tabular}

Note: The variable "EMINDEX" represents the CRSP equally-weighted monthly market index. Event periods are represented by the following dummy variables: D1: January 1950-December 1950 (journal reports on lung cancer); D2: September 1953-August 1954 (fear advertising); D3: July 1955-November 1955 (FTC Cigarette Advertising Guides): D4: December 1959-December 1961 (FTC ban on tar and nicotine claims); D5: January 1962-October 1962 (Royal College of Physicians report): D6: December 1963-July 1965 (Surgeon General's report).

***significant at the $1 \%$ level

** significant at the $5 \%$ level

*significant at the $10 \%$ level

The fifth event period begins two months before the March 1962 release of the Report of the Royal College of Physicians and ends approximately four months after Readers Digest (1962) published a June article highlighting results of that report.

The sixth event period begins two months before the January 1964 release of the Surgeon General's Report and ends July 1965, the month President Johnson signed the bill requiring health notices on cigarette packages.

\section{Results}

In Table 1, we present the results of the seemingly unrelated regression estimation for the equation system defined by Equation 3, which yields average abnormal returns for each firm for each event period. In Table 2, we present estimation results for Equation 4, which tests for each event period the joint hypothesis that the entire group of five firms was unaf- fected. Table 3 contains the results of Equation 5, which tests hypotheses about differential impacts on large versus small firms for each event period.

The regression results indicate significant negative impacts on four of the five cigarette firms (Philip Morris did not have a statistically significant abnormal return) during the first event period when the first cancer reports were being released. These impacts ranged from a decline of approximately $-1.7 \%$ for American Tobacco and Liggett \& Myers to approximately $-2.4 \%$ for R. J. Reynolds and Lorillard. The average impact for the industry as a whole was approximately $-1.8 \%$, which was statistically significant. There was no statistically significant difference between the impact on the two large firms (American Tobacco and R. J. Reynolds) and the three smaller firms.

The second event period, characterized by fear advertising, exhibited a significant negative impact on all firms in 
the industry. The abnormal returns ranged from approximately $-1.8 \%$ for Liggett \& Myers to $-3.0 \%$ for Philip Morris. For the industry as a whole, the average impact was approximately $-2.3 \%$. These data provide no support for the hypothesis that fear advertising benefited the smaller firms at the expense of the larger ones, because there was no statistically significant difference between the impact on the large firms versus the impact on the smaller firms.

The results of the third event period are consistent with the hypothesis that the 1955 FTC advertising guides benefited the larger firms. Although none of the firms displayed statistically significant individual abnormal returns (though the results for American Tobacco were close to being significant), the difference between the average impact for the two larger firms and that for the smaller firms was statistically significant. The average impact for American Tobacco and R. J. Reynolds was approximately $+1.9 \%$ whereas it was only approximately $+.3 \%$ for the three smaller firms.

The results of the fourth event period are consistent with the hypothesis that the 1960 FTC "voluntary" ban on tar and nicotine advertising benefitted the industry overall, but did so mainly by benefiting larger firms. American Tobacco and R. J. Reynolds displayed statistically significant individual abnormal returns, these being approximately $+1.5 \%$ for the former and approximately $+2.0 \%$ for the latter. Philip Morris (then still relatively small) also displayed a statistically significant abnormal return of $+1.2 \%$. Most important, however, the difference between the average impact for the two larger firms (approximately $+1.8 \%$ ) and the three smaller firms (approximately $+.5 \%$ ) was statistically significant. For the industry as a whole, the average impact was approximately $+1.0 \%$, which was statistically significant.

The fifth event period, which included the March 1962 Report of the Royal College of Physicians, exhibited statistically significant negative abnormal returns for all five firms. These ranged from approximately $-2.8 \%$ for Lorillard to less than $-5.6 \%$ for R. J. Reynolds. The average impact for the industry as a whole was approximately $-3.7 \%$, which was statistically significant. There was a statistically significant differential impact between the larger and smaller firms, with the negative effect greater for the larger firms.

Table 2. F-Tests for Joint Hypothesis in Equation 4a

\section{Event Period Dummy} (see Table 1)

DI

D2

D3

D4

D5

D6

F Value
$6.5578^{* * *}$
$9.9487^{* * *}$
.7559
$2.9990^{*}$
$15.4148^{* * *}$
.5169

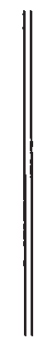

Average of the Event-Period Average Excess Returns

$(\mathrm{I} / \mathrm{N}) \Sigma_{i} \delta_{i 1}=-.01818$

$(1 / N) \Sigma_{i} \delta_{i 2}=-.02265$

$(\mathrm{l} / \mathrm{N}) \Sigma_{i} \delta_{i 3}=.00949$

$(\mathrm{I} / \mathrm{N}) \Sigma_{i} \delta_{\mathrm{i} 4}=.01038$

$(\mathrm{l} / \mathrm{N}) \Sigma_{;} \delta_{\mathrm{i} 5}=-.03697$

$(1 / N) \Sigma_{i} \delta_{i 6}=-.00490$

${ }^{a} H_{0}:$ The Average of the Event-Period Average Excess Returns $=0$ (i.e., $\left[1 / \mathrm{N} \mid \Sigma_{\mathrm{i}} \delta_{\mathrm{ia}}=0\right)$.

***significant at the $1 \%$ level

**significant at the $5 \%$ level

*significant at the $10 \%$ level 
The results of the analysis suggest that (1) the first cancer reports of 1950 substantially reduced stock returns of four of the five cigarette firms, an interesting result in light of the common view that it was not until 1953 and 1954 that observers noted (and econometric analyses later found) an association between health information and reduced sales; (2) the episode of fear advertising in 1953-54, which was associated with an unrivaled decline in sales, also was associated with a decline in the market valuations of all cigarette firms; (3) the cessation of fear advertising in the fall of 1955 , coincident with a new FTC policy guide that prohibited such claims, brought a recovery in stock returns, particularly for the largest firms; (4) the "voluntary" ban on tar and nicotine advertising, which was engineered by the FTC in February 1960, appeared to have a strong positive effect on stock returns of the two largest firms; (5) stock returns of all five firms declined significantly during a period that roughly coincided with publicity about the British Royal College of Physicians 1962 report on smoking and health; and (6) the 1964 Surgeon General's report and the subsequent cigarette package labeling law were associated with no remarkable movements in stock returns.

One implication of these findings is that new adverse health information tended to affect industry earlier than is generally assumed: in 1950 and 1951 (when the earliest reliable cancer reports were published) and in wake of the 1962 Royal College of Physicians report, rather than after the 1964 Surgeon General's Report. A second implication is that competitive forces aroused in 1953 and 1954 by the cancer reports tended to harm the industry (just as price wars and other more traditional forms of competition do), while arguably adding to consumer information about smoking and health. A third implication (familiar from the economics of regulation) is that regulatory actions targeted at an industry do not necessarily harm that industry-even when the interventions have popular appeal and the industry is unpopular. We must therefore avoid simple assumptions about regulation's impact on consumers versus industry. Our results suggest that spontaneous informational shocks and competitive reactions (such as the cancer reports of 1950, which brought the fear advertising of 1953-54) hurt the industry while encouraging consumers to smoke less, whereas regulatory intervention served mainly to dampen these same effects. Thus, the FTC's 1955 "Cigarette Advertising Guides" and the 1960 ban on tar and nicotine advertising were presumably designed to improve consumer information even at the cost of harming the industry, but the opposite effects seem to have occurred. Previously cited work on the 1971 broadcast advertising ban, which was supported by the industry, is largely consistent with this view (Mitchell and Mulherin 1988).

Also of interest are regulation's differential effects within the industry. We found that the two regulatory interventions under review (the "Cigarette Advertising Guides" and the 1960 ban on tar and nicotine advertisements) tended to favor larger firms. This is consistent with the notion (again widely supported in the economics of regulation literature) that regulation often makes markets less competitive, with the benefits flowing to large firms. The subsequent history of cigarette advertising regulation supports this view. When the FTC finally decided in 1966 to encourage tar and nicotine claims, the industry's self-regulation body resisted the new policy even as smaller firms moved quickly to exploit it (Calfee 1985, 1986).

All these findings suggest the continuing importance of making an independent assessment of the likely effects of proposed advertising bans and other interventions in informational competition. Industry opposition is not necessarily an indication of consumer benefits, and the obvious corollaries of that statement also apply. We believe it is hardly coincidental that the dominant marketers of cigarettes and smokeless tobacco recently infuriated their competitors and the advertising industry by announcing their support for much of the FDA's proposed restrictions on advertising and marketing, even as a competing cigarette manufacturer already mired in controversy prepared to introduce a new smokeless cigarette whose success would undoubtedly require intense advertising support (Advertising Age 1996; New York Times 1996; Wall Street Journal 1996). Thus, subtle interactions among competitors and regulators continue unabated in an always fascinating industry.

\section{References}

Advertising Age (1996), "Ad Groups Rally Against Philip Morris," (June 3), 54.

Beales, H., R. Craswell, and S. Salop (1981), "The Efficient Regulation of Consumer Information," Journal of Law and Economics, 24 (December), 491-539

Binder, J. J. (1985), "Measuring the Effects of Regulation With Stock Price Data," Rand Journal of Economics, 16 (Summer), 167-83.

Bishop, J. A. and J. H. Yoo (1985), “'Health Scare,' Excise Taxes and Advertising Ban in the Cigarette Demand and Supply," Southern Economic Journal, 52, 402-11.

Brecher, E. et al. (1963), The Consumers Union Report on Smoking and the Public Interest. New York: Mount Vernon.

Burney, L. (1958) "Statement, July 12, 1957," Ca. Bulletin of Cancer Progress, 8 (March/April), 44.

Business Week (1953a), "Fears and Jitters," (November 14), 54. (1953b), (November 21), 145. (1954), (June 19), 58.

Calfee, J. E. (1985), "Cigarette Advertising, Health Information and Regulation before 1970," Working Paper \#134, Bureau of Economics, Federal Trade Commission.

(1986), "The Ghost of Cigarette Advertising Past," Regulation, (November/December), 35-45.

(1987), "Cigarette Advertising Regulation Today: Unintended Consequences and Missed Opportunities," in Advances in Consumer Research, Vol. 14, P. Anderson and M. Wallendorf, eds. Provo, UT: Association for Consumer Research, 264-68.

Cipollone v. Liggett Group, Inc., Philip Morris, Inc., and Lorillard, Inc. (1992), slip opinion, Supreme Court, June 24, 1992.

Consumer Reports (1952), "Kent Cigarettes: Are the Advertising Claims Made in Their Behalf Justified"? (June), 262.

(1953a), (February), 58-73.

(1953b), Buying Guide for 1954, (December).

(1957), "Medical Aspects: The Cancer Linkage Is Still Not Clear," (March), 107-110. 
Doll, R. and A. B. Hill (1950), "Smoking and Carcinoma of the Lung," British Medical Journal, 2, 739-48.

- and (1952), "A Study of the Aetiology of Carcinoma of the Lung," British Journal of Medicine, 2, 1271-86.

and _- (1954), "The Mortality of Doctors in Relation to Their Smoking Habits: A Preliminary Report," British Medical Journal, 1, 1451.

Drew, E. (1965), "The Quiet Victory of the Cigarette Lobby," Atlantic Monthly, (September), 77.

Eckard, E. W. (1991), "Competition and the Cigarette TV Advertising Ban," Economic Inquiry, 29 (1), 199-33.

Fama, E. F., L. Fisher, M. Jensen, and R. Roll (1969), “Adjustment of Stock Prices to New Information," International Economic Review, 10 (February), 1-21.

Federal Trade Commission (1955), "Cigarette Advertising Guides," Trade Reg. Rep. (CCH), Section 39,0121, 1960, Reprint in Annual Report, Washington, DC: Federal Trade Commission, 1964, Reprint in "Staff Report, Trade Regulation Rule for the Prevention of Unfair or Deceptive Advertising and Labeling of Cigarettes in Relation to the Health Hazards of Smoking," Washington, DC: Federal Trade Commission.

(1960), "Voluntary Ban on Tar and Nicotine Advertising," 2 Trade Reg. Rep. (CCH), Section 7853.51.

(1964), Staff Report, Trade Regulation Rule for the Prevention of Unfair or Deceptive Advertising and Labeling of Cigarettes in Relation to the Health Hazards of Smoking. Washington, DC: Federal Trade Commision.

(1979), Consumer Information Remedies. Washington, DC: Federal Trade Commision.

Food and Drug Administration (1995), "Regulation Restricting the Sale and Distribution of Cigarettes and Smokeless Tobacco Products to Protect Children and Adolescents," Docket No. 95N-0253, 60/155 Fed. Reg. 41314.

Ford, G. T., D. J. Ringold, and M. Rogers (1990), "Tobacco in the Popular Press, 1930-1960: Preliminary Research," in Advances in Consumer Research, Vol. 17, Marvin E. Goldberg, Gerald Gorn, and Richard W. Pollay, eds. Provo, UT: Association for Consumer Research, 467-73.

Fortune (1953), “The Uproar in Cigarettes," (December), 130. 100.

(1963), "Embattled Tobacco's New Strategy," (January),

Franke, George (1994), "U.S. Cigarette Demand, 1961-1990: Econometric Issues, Evidence, and Implications," Journal of Business Research, 30, 33-41.

Ippolito, R. A., R. D. Murphy, and D. Sant (1979), Staff Report on Consumer Responses to Cigarette Health Information. Washington, DC: Bureau of Economics, Federal Trade Commission.

Kintner, E. (1960), "Statement to Advertising Federation of America," reproduced in Trade Reg. Rep., (CCH) section 7853, (February 5$), 12,740$.

Laugesen, Murray and Chris Meads (1991), "Tobacco Advertising Restrictions, Price, Income and Tobacco Consumption in OECD Countries, 1960-1986," British Journal of Addiction, 86, 1343-54.

Lieb (1953), "Can the Poisons in Cigarettes Be Avoided?" Readers Digest, (December), 45-47.

Lubatkin, M. and Shrieves, R. (1986), "Towards Reconciliation of Market Performance Measures of Strategic Management Research," Academy of Management Review, 11, 497-512.
Maxwell, J. C., Jr. (1964), "Cigarette Marketing: What's Ahead?" Printer's Ink, (February 4), 28.

(1986), Historical Sales Trends in the Cigarette Industry: A Statistical Summary Covering 6I Years (192l-85). New York: Furman Selz Mager Dietz and Birney.

McAuliffe, R. E. (1987), Advertising, Competition, and Public Policy: Theories and New Evidence. Lexington, MA: Lexington Books.

(1988), "The FTC and the Effectiveness of Federal Cigarette Advertising Regulation," Journal of Public Policy \& Marketing, 7, 49-64.

Miles, R. (1982), Coffin Nails and Corporate Strategies. Englewood Cliffs, NJ: Prentice-Hall.

Miller, L. and Monahan, J. (1954), "The Facts Behind the Cigarette Controversy," Readers Digest, (July), 1-6.

and (1957a), "The Facts Behind Filter-Tip Cigarettes," Readers Digest, (July), 33-39.

and - (1957b), "Wanted-And Available-FilterTips That Really Work," Readers Digest, (August), 43-49.

Mitchell, M. and H. H. Mulherin (1988), "Finessing the Political System: The Cigarette Advertising Ban," Southern Economic Journal, 54, 855-62.

New York Times (1954), advertisement, (January 6).

(1960), (February 8), 8.

(1996), "A Safer Smoke or Just Another Smokescreen? Reynolds Courts Support for a New Product," (April 12), D1.

Norr, N. (1952), "Cancer by the Carton," Readers Digest, (December), 7-8.

Porter, R. H. (1986), "The Impact of Governmental Policy on the U.S. Cigarette Industry," in Empirical Approaches to Consumer Protection Economics, P. Ippolito and D. Scheffman, eds. Washington, DC: Bureau of Economics Report, Federal Trade Commission, 447-82.

Readers Digest (1962), "Lung Cancer and Cigarettes: Here Are the Latest Findings," (June), 45-50.

(1963a), "The Cigarette Controversy: A Storm is Brewing," (August), 91-98. (1963b), "Report to Consumers," (August), 99.

Ringold, D. J. and J. E. Calfee (1989), "The Informational Content of Cigarette Advertising: 1926-86," Journal of Public Policy \& Marketing, 8, 1-23.

— and (1990), "What Can We Learn From the Informational Content of Cigarette Advertising? A Reply and Further Analysis," Journal of Public Policy \& Marketing, 9, 30-41.

Rose, N. I. (1985), "The Incidence of Regulatory Rents in the Motor Carrier Industry," Rand Journal of Economics, 16 (Autumn), 299-318.

Royal College of Physicians (1962), Smoking and Health. London: Pitman.

Schneider, L., B. Klein, and K. Murphy (1981), "Governmental Regulation of Cigarette Health Information," Journal of Law and Economics, 24, 575-612.

Simonich, William L. (1991), Government Anti-Smoking Policies. New York: Peter Lang Publishing.

Smith, R. T., M. Bradley, and G. Jarrell (1986), "Studying FirmSpecific Effects of Regulation With Stock Market Data: An 
Application to Oil Price Regulation," Rand Journal of Econom. ics, 17 (Winter), 467-89.

Stewart, Michael J. (1992), "Tobacco Consumption and Advertising Restrictions: A Critique of Laugesen and Meads (1991)," International Journal of Advertising, 11, 97-118.

Theil, H. (1971), Principles of Econometrics. New York: John Wiley \& Sons.

Troyer, R. J. and G. E. Markle (1983), Cigarettes: The Battle Over Smoking. New Brunswick, NJ: Rutgers University.

U.S. Public Health Service (1964), Smoking and Health: Report of the Advisory Committee to the Surgeon General, Doc. \# 1103. Washington, DC: U.S. Public Health Service

Wagner, S. (1971), Cigarette Country: Tobacco in American History and Politics. New York: Praeger.

Wall Street Journal (1996), "Philip Morris Proposes Curbs on Sales to Kids," (May 16), B1.

Warner, K. (1979), "Clearing the Airwaves: The Cigarette Ad Ban Revisited," Policy Analysis, 5, 435-50.

et. al. (1986), "Promotion of Tobacco Products: Issues and Policy Options," Journal of Health Politics, Policy and Law, 11, 367-92. and H. Murt (1982), "Impact of the Antismoking Campaign on Smoking Prevalence: A Cohort Analysis," Journal of Public Health Policy, 3, 374-90.

Wootten, H. (1956), "Cigarette Output Up 4.8\%-Filters Up 59.\%," Printer's Ink, (December 28), 11.

(1957), "Filters Push Cigarette Sales Up 4.9\%," Printer's Ink, (December 27), 22.

(1958), "Cigarette Sales in 1958: Tobacco Men Do 5\% Better," Printer's Ink, (December 26), 11.

Wynder, E. L. (1988), "Tobacco and Health: A Review of the History and Suggestions for Public health Policy," Public Health Reports, 103 (January/February), 8-18.

and F. Graham (1950), "Tobacco Smoking as a Possible Etiologic Factor in Bronchogenic Carcinoma," Journal of American Medical Association, 143 (March 27), 329-36.

E. Graham, and A. Croninger (1953), "Experimental Production of Carcinoma with Cigarette Tar: Part I," Cancer Research, 13, 855 .

Zellner, A. (1962), "An Efficient Method of Estimating Seemingly Unrelated Regressions and Tests for Aggregation Bias," Journal of the American Statistical Association, 57 (June), 348-68. 
Copyright of Journal of Public Policy \& Marketing is the property of American Marketing Association and its content may not be copied or emailed to multiple sites or posted to a listserv without the copyright holder's express written permission. However, users may print, download, or email articles for individual use. 